\title{
FUNCTIONAL ANALYSIS IN THE EVALUATION OF FOUR CONCEPTS OF PLANTERS
}

\author{
EMPREGO DA ANÁLISE FUNCIONAL NO JULGAMENTO DE \\ QUATRO CONCEPÇÕES DE SEMEADORAS
}

\author{
Ângelo Vieira dos Reis ${ }^{1}$ Fernando Antônio Forcellini ${ }^{2}$
}

\section{SUMMARY}

\begin{abstract}
The essential functions of a planter are to open the planting furrow, meter the seeds, deposit them in the furrow, cover them and compact the soil around them. The planter precision is affected, in some way, by each of those functions. Function analysis is a tool used in the conceptual phase of product design which allows an abstract formulation for the function of the technical system, thus making it very useful in product design and in the analysis of existing products. Therefore, the technique of function analysis makes it possible to identify, in the various concepts of planters sold in the Brazilian market, which function is not well implemented when considering precision planting of small grains, being this the main objective of this study. This study has made it possible to conclude, among other things, that in all concepts of planters analyzed, the subfunctions of metering seeds and that of depositing seeds in the soil were not satisfactorily implemented for the precision planting of small grains. This points out the need of searching for other concepts of planters or the adoption of different solution principles for these functions.
\end{abstract}

Key words: precision planting, machinery design, small seeds.

\section{RESUMO}

As principais funções de uma semeadora são: abrir o sulco de semeadura, dosar sementes, depositá-las no sulco, cobri-las e compactar o solo em torno delas. Todas influem, de alguma forma, na precisão de semeadura. A análise funcional é uma ferramenta de projeto utilizada na fase de projeto conceitual dos produtos, que tem como característica permitir uma formulação abstrata da função do sistema técnico, independente de qualquer solução particular, o que a torna de grande utilidade no projeto de produtos e na análise de produtos já existentes. Sendo assim, com a técnica da análise funcional é possível

\begin{abstract}
identificar nas várias concepções de semeadoras existentes no mercado brasileiro, quais as funções inadequadamente implementadas tendo em vista a semeadura de precisão de grãos miúdos, que é o objetivo deste trabalho. $O$ estudo que foi conduzido permitiu concluir, entre outras coisas, que em todas as concepções consideradas as funções parciais de dosar sementes $e$ de depositar sementes no solo não se apresentam satisfatórias quando se considera a semeadura de precisão de sementes miúdas, o que aponta para a necessidade de se buscar outras concepções de semeadora ou adotar outros princípios de solução para essas funções.
\end{abstract}

Palavras-chave: semeadura de precisão, projeto de máquinas, sementes miúdas.

\section{INTRODUCTION}

The success of cultivating a crop is strongly related to the seeding process. In this process, the machine factor has special importance, since it is responsible for the spatial distribution of plants, which in turn greatly affects the productivity of crops. The present work deals with the problematic of the machine factor, specially with the issues related to precision seeding.

The overall functions of a planter are, according to KEPNER et al. (1982), to open the seed furrow to the proper depth, meter the seeds, deposit the seeds in the furrow in an acceptable pattern, cover the seeds and compact the soil around them. In the precision seeding the metering device allows the placement of seeds at preset distances among them in the furrow.

\footnotetext{
${ }^{1}$ Engenheiro Agrícola, Professor Adjunto, Departamento de Engenharia Rural, Faculdade de Agronomia Eliseu Maciel, Universidade Federal de Pelotas. Doutorando em Engenharia Mecânica, NeDIP, CTC, Universidade Federal de Santa Catarina (UFSC), CP 476, 88040-900, Florianópolis, SC. Fone: (48)331-9719. E-mail: areis@ @edip.ufsc.br. Autor para correspondência.

${ }^{2}$ Engenheiro Mecânico, Professor Adjunto, Departamento de Engenharia Mecânica, CTC, UFSC. E-mail: forcellini@emc.ufsc.br.
} 
According to REIS (2000), the seed metering device is not the only responsible for the planters' performance concerning precision. The metered seed still has to be carried to the bottom of the furrow (opened at a certain depth) and properly conditioned. The quality of these operations decisively affects the seedling emergence index (number of viable seeds delivered to the emerged seedlings ratio), which is one of the parameters used to evaluate the final performance of a precision planter (PORTELLA et al., 1997). Thus, when a precision planter is thought of, either in terms of design or in terms of field operation, it is necessary to consider the effect of various mechanisms upon the seed longitudinal distribution regularity and, therefore, upon plants along the furrow.

Functional analysis is used as a tool in some methodologies with a systematic approach to the product design process, as in the one proposed by PAHL \& BEITZ (1996). This specific methodology, with little improvements, is being successfully employed by the Group of Integrated Product Development (NeDIP) at Universidade Federal de Santa Catarina.

The design methodology used at NeDIP divides the design process into four phases: informational design (collecting information about the design task and formulation of the product specifications); conceptual design (generation of a concept for the product by fulfilling the customer's needs as much as possible - this is where the functional analysis is present); embodiment design (development of the product's concept according to technical and economical criteria); detail design (the design final phase, where the arrangement, form, dimension and allowances of all parts are finally established).

In general it can be said, as FERREIRA (1997) points out, that the conceptual design process is divided in two parts: analysis (starting point in abstract field, functional analysis, decomposition) and synthesis (composition, arrangement of solutions, proximity of the concrete field). This author also explains that a concept is, above all, an idea of what the product is or of what it is going to $b e$, being invested of a set of means to perform the intended function, as well as spatial and structural relationship among such means.

According to PAHL \& BEITZ (1996), all technical systems deal with conversions of energy, matter and information, which must be defined quantitatively, qualitatively and economically, so that the system output, relating these three parameters, is conditioned by its function and by the input. Therefore, once the task of a given system, whether real or designed, is fixed, the function takes the abstract formulation of this task, independently of any particular solution. This characteristic of the functional analysis is of great help when designing new products and in the analysis of existing products, as in the present study.

Still according to PAHL \& BEITZ (1996), in the functional analysis the overall function of the system, the one that establishes the relationship among all inputs and outputs involved, as well as their properties, must be judiciously determined. Because the overall function of a system is usually too complex to allow the identification of a solution principle that alone could fulfill the system purpose, it is necessary to break it down in less complex sub-functions. This decomposition must proceed until a solution principle able to perform alone the system task (elementary functions) can be found. The meaningful and appropriated arrangement of the sub-functions of the overall function is named function structure, which is generally represented by block diagrams.

Realizing, therefore, that the functional precision of planters depends on the proper work of various mechanisms of the machine, and that the functional analysis has the potential of representing a technical system through an overall function and its elementary functions properly arranged in a function structure, the present work proposes a generic study of the planters available in the Brazilian market in order to identify, among the subfunctions related to seeding precision, which of them present physical solutions that make them inefficient when precision seeding of small seeds is considered.

The idea of performing an indirect and generic evaluation of planters has already been used. FERREIRA et al. (1997) used the technological coefficient to evaluate no-till planters. Every mechanism of the machine was analyzed according to the level of technology employed. The main idea is to perform a fast analysis, observing the mechanisms directly and/or to use information from the user's guide or producer's catalogues, without the need of field tests and without disassembling any part of the planter. Ten main systems are analyzed. Desirable conditions (respect to norms, application of the best technique) are fixed for each of them, as well as their score.

\section{MATERIAL AND METHODS}

The first part of the study is the identification of concepts of planters existing in the 
Brazilian market. The identification of concepts was based on recent folders of planters sent by the manufactures, collected in farm shows and authorized dealers.

Once the concepts were set up, the functional analysis itself began. The first step was the establishment of the overall function of a precision planter based on the task that has to be performed. Afterwards, based on the study of KEPNER et al. (1982), the overall function was decomposed into sub-functions of less complexity and from these to the elementary functions, that is, low level functions where it is possible to find a concrete physical solution to perform them, in order to obtain the system function structure. A function structure able to satisfy all concepts of planters considered was adopted in this study. Thus, it is possible to compare all of them based on the same elementary functions.

After the establishment of a function structure adequate to the considered concepts, the commercial folders of the planters were used to find the solution principles (physical solutions) employed to perform each function in a specific concept. With this information, it was then possible to infer about the adequacy of each concept of planters used in precision seeding, either large seeds - where these planters are already used - or in small seeds, which is the matter studied by the authors. The analysis of adequacy of the various solution principles used in the concepts was based on a study carried out by REIS \& ALONÇO (2001) about evaluation and tests of planters conducted in Brazil in 13 researches.

\section{RESULTS AND DISCUSSION}

The study of the commercial folders of planters for irrigated rice (sowing) and for precision seeding of large grains has allowed grouping the distinct machines into four design concepts, which are presented in figure 1 and textually described as follows:

Concept I: small seeds machine, high metering device, gravity delivery of seeds to soil.

Concept II: large seeds precision machine, high metering device, gravity delivery of seeds to soil.

Concept III: large seeds precision machine, high metering device, positive delivery of seeds to soil.

Concept IV: large seeds precision machine, low metering device, gravity delivery of seeds to soil.
The position of the seed metering device in the machine (low or high) is relative to ground level. The metering device was considered high if it was fixed directly onto the planters' main structure and, therefore, away from the ground. Conversely, the metering device was considered low when fixed onto seeding row structure and, therefore, near the ground.

Another aspect that functionally distinguished the planters analyzed was the way in which the metered seed was conducted to the bottom of the furrow. In most cases this function is performed only with the help of gravity upon the seed, while in some, an air jet inside the seed tube forces the movement of the seeds to the furrow.

Concept IV may have the seed hopper directly over the seed meter or, as in some cases, may have a large seed hopper onto the main structure connected to a small reservoir with the metering device on the seeding row structure, as shown in figure 1 .

The overall function of the seeders is shown in figure 2 . The decomposition of this function into sub-functions and afterwards in elementary functions is illustrated in figures 3 and 4 , respectively.

The study of these planters has allowed the identification of the main solutions adopted to perform the elementary functions shown in figure 4, as presented in table 1 . In the same way, it was possible to identify, with the aid of the bibliography, which of the elementary functions are not properly implemented when the precision seeding of small grains is to be considered (Table 2). This information can be of great value in designing planters, because it favors the use of new concepts and the adoption of better suited solution principles.

The results analysis shows the lack of adequacy of the present concepts to perform in a satisfactory manner the sub-function meter seeds (F2). In all concepts there are limitations in the solutions adopted when the precision seeding of small seeds is considered. Even in Concept III, the use of pneumatic metering devices which, according to CASÃO JUNIOR (1996), are well adapted to seeds of various shapes and sizes, presents drawbacks because they have a large lateral dimension, which make them unsuitable as long as small distances between furrows are needed in small grain crops.

To an equal degree, the sub-function deliver seeds (F4) presents limitations in all concepts studied. The major one is the adoption of too long delivery tubes (due to very high metering devices) 

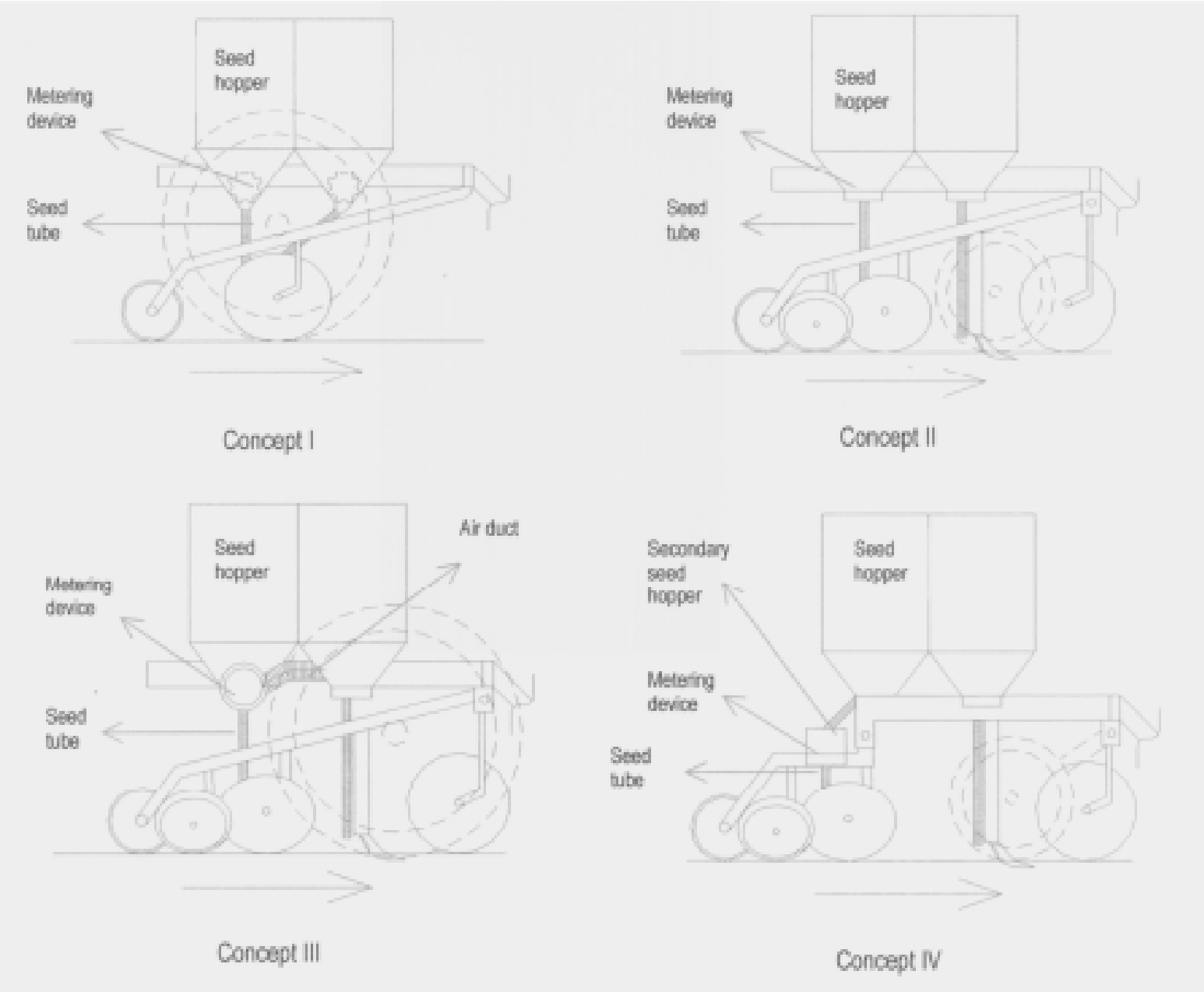

Figure 1 - Graphical representation of the enrolled concepts.

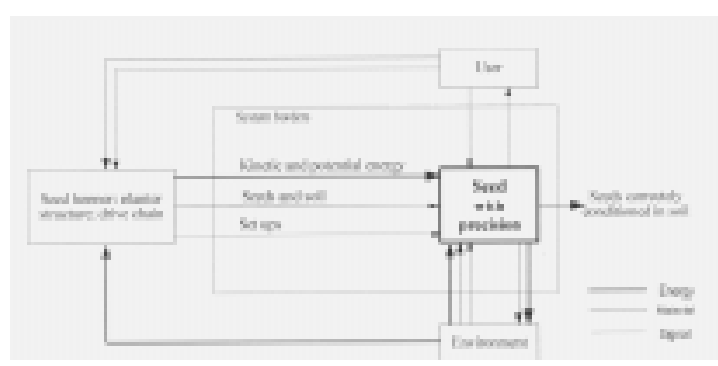

Figure 2 - Overall function of a precision planter.

which, according to KEPNER et al. (1982), increases the delivery errors because the path of seeds inside a long tube varies from seed to seed. Even in Concept $I V$, which uses a short tube and the metering device close to the ground, it is not optimal because in most planters the seed tube is not inclined backwards in order to minimize the random rolling of the seeds inside it, as

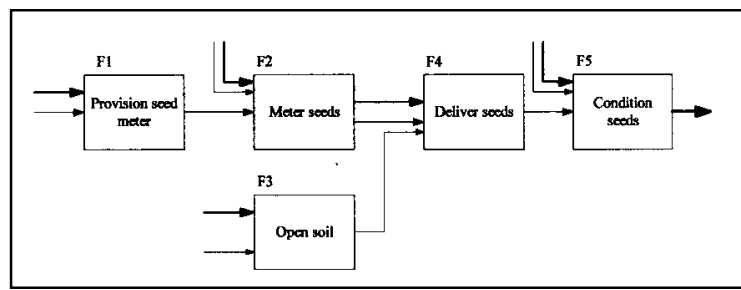

Figure 3 - Function structure showing the sub-functions of a precision planter.

recommended by PACHECO et al. (1996). These limitations may affect the planters' performance in the precision seeding of both large and small seeds.

Although Concepts II, III and IV do not have an entirely satisfactory solution to the elementary function control depth (F33), this is not really a problem, because on seeders of small seeds (Concept $I$ ) this function is adequately performed. So, those solutions could be applied to the design of 


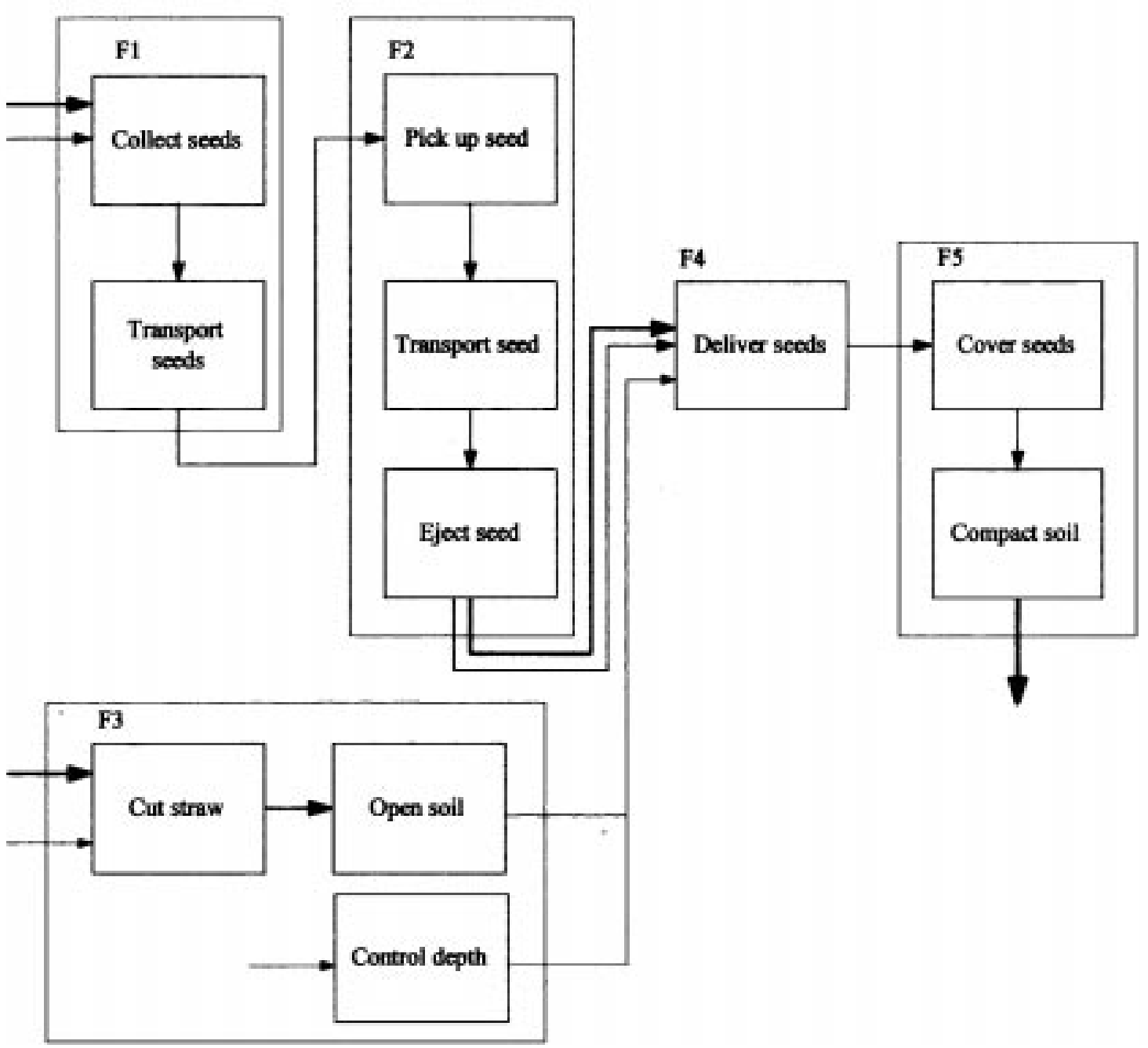

Figure 4 - Function structure showing the elementary functions of a precision planter.

small seeds precision planters, where there is the need for small inter-furrows distances.

\section{CONCLUSIONS}

The results of this study, along with their discussion, allows drawing some conclusions about the use of the functional analysis in the evaluation of planters and also about the performance of these planters in a generic way. Thus, the following conclusions are drawn:

a) The judicious use of the functional analysis technique is viable in the evaluation of planters, since the results are coherent and are in agreement with those of other researchers. It is believed that this technique may be extended to the generic evaluation of other agricultural machinery. b) The use of functional analysis allows the identification of badly implemented functions on the planter, therefore guiding the design process, since a greater amount of efforts can be used to solve well known problems.

c) Regarding the concepts studied, it was noted that in none of them the adopted solutions to implement the sub-function meter seeds are satisfactory to precision seeding of small seeds, which points out the need of searching other concepts or the adoption of a better suited solution principle for this sub-function.

d) The same inadequacy of the adopted solution principles in the four concepts enrolled was noticed in the sub-function deliver seeds, in both the seeding of large seeds (actual use) and in the precision seeding of small seeds crops (in project). 
Table 1 - Solutions adopted in four concepts of planters on the Brazilian marker.

\begin{tabular}{|c|c|c|c|c|}
\hline Elementary functions & Concept I & Concept II & Concept III & Concept IV \\
\hline F11: collect seeds & Does not apply & Does not apply & Does not apply & Hole \\
\hline F12: transport seeds & Does not apply & Does not apply & Does not apply & Flexible tube; gravity \\
\hline F21: pick up seed & Fluted feedcup & Horizontal plate $^{*}$ & Pneumatic & Horizontal plate ${ }^{*}$ \\
\hline F22: transport seed & Rotation & Rotation & Rotation & Rotation \\
\hline F23: eject seed & Gravity & $\begin{array}{l}\text { Mechanical knock- } \\
\text { out device }\end{array}$ & Not identified & Not identified \\
\hline F31: cut straw & F31=F32; Disk coulter & Single disk & Single disk & Single disk \\
\hline F32: open soil & & Disk coulter & Disk coulter & Disk coulter \\
\hline F33: control depth & Rims on Disk coulter ${ }^{*}$ & Packing wheel & External wheels ${ }^{*}$ & External wheels ${ }^{*}$ \\
\hline F4: deliver seeds & Flexible tube; gravity & $\begin{array}{l}\text { Flexible tube; } \\
\text { gravity }\end{array}$ & Flexible tub, forced by air jet & Rigid tube; gravity \\
\hline F51:cover seeds & $\begin{array}{c}\text { F51=F52; packing } \\
\text { wheel with }\end{array}$ & Inclined disks & $\begin{array}{l}\text { F51=F52; Disk coulter } \\
\text { internal wheel }\end{array}$ & $\begin{array}{c}\mathrm{F} 51=\mathrm{F} 52 ; \text { inclined } \\
\text { disks }\end{array}$ \\
\hline F52: compact soil & trapezoidal section & Rubber wheel & and inclined disks ${ }^{\dagger}$ & \\
\hline
\end{tabular}

*The most used, may present variations.

${ }^{\dagger}$ Solution adopted by one maker.

Table 2 - Adequacy of the solution adopted in the four concepts enrolled to the precision seeding of small seeds.

\begin{tabular}{|c|c|c|c|c|}
\hline Elementary functions & Concept I & Concept II & Concept III & Concept IV \\
\hline \multicolumn{5}{|l|}{$\begin{array}{l}\text { F11: collect seeds } \\
\text { F12: transport seeds }\end{array}$} \\
\hline F21: pick up seed & $\begin{array}{l}\text { Drill seeding, very low } \\
\text { precision }\end{array}$ & $\begin{array}{l}\text { Not precise for small } \\
\text { seeds; large lateral } \\
\text { dimension }\end{array}$ & Large lateral dimension & $\begin{array}{l}\text { Not precise for small seeds; } \\
\text { large lateral dimension }\end{array}$ \\
\hline F22: transport seed & $\begin{array}{c}\text { Potential to damage } \\
\text { seeds }\end{array}$ & & & \\
\hline F23: eject seed & $\begin{array}{l}\text { The knockout of seeds } \\
\text { is not simultaneous }\end{array}$ & $\begin{array}{l}\text { Potential to damage } \\
\text { seeds }\end{array}$ & & \\
\hline \multirow{2}{*}{$\begin{array}{l}\text { F31: cut straw } \\
\text { F32: open soil } \\
\text { F33: control depth }\end{array}$} & & & & \\
\hline & & $\begin{array}{c}\text { Device too far from } \\
\text { opener (response } \\
\text { delay) }\end{array}$ & Large lateral dimension & Large lateral dimension \\
\hline F4: deliver seeds & $\begin{array}{c}\text { Tube too long, prone } \\
\text { to cause delivery } \\
\text { errors }\end{array}$ & $\begin{array}{c}\text { Tube too long, prone } \\
\text { to cause delivery } \\
\text { errors }\end{array}$ & $\begin{array}{l}\text { Tube too long, prone to } \\
\text { cause delivery errors } \\
\text { (even with air jet) }\end{array}$ & $\begin{array}{l}\text { Adequate, but the seed tube } \\
\text { is generally vertical }\end{array}$ \\
\hline $\begin{array}{l}\text { F51:cover seeds } \\
\text { F52: compact soil }\end{array}$ & & & & \\
\hline
\end{tabular}

\section{REFERENCES}

CASÃO JUNIOR, R. Desenvolvimento de sistema pneumático de dosagem e transporte de sementes. 1996. $191 \mathrm{p}$. Tese (Doutorado em Engenharia Mecânica) - Faculdade de Engenharia Mecânica, Universidade Estadual de Campinas, Campinas, 1996.

FERREIRA, M.G.G. Utilização de modelos para a representação de produtos no projeto conceitual. 1997. 128p. Dissertação (Mestrado em Engenharia Mecânica) CTC/EMC, Universidade Federal de Santa Catarina, Florianópolis, 1997.

FERREIRA, M.F., NEUJAHR, E. B., DALLMEYER, A. U., et al. Coeficiente tecnológico de semeadoras para semeadura direta. Santa Maria, 1997. 61p. Dissertação (Mestrado em Engenharia Agrícola) - Centro de Ciências
Rurais, Universidade Federal de Santa Maria, Santa Maria, 1997.

KEPNER, R.A., BAINER, R., BARGER, E.L. Principles of farm machinery. $3^{\text {rd }}$ ed. Westport : Avi , 1982. 527p.

PAHL, G., BEITZ, W. Engineering design: a systematic approach. $2^{\text {nd }}$ ed. London : Springer-Verlag, 1996. 544 p.

PACHECO, E.P., MANTOVANI, E. C., MARTYN, P. J., et al. Avaliação de uma semeadora-adubadora de precisão. Pesq Agropec Bras, Brasília, v.31, n.3, p.209-14, 1996.

PORTELlA, J.A., SATTLER, A., FAGANELlO, A. Avaliação de índices de emergência de soja e de milho em plantio direto no sul do Brasil. In: CONGRESSO BRASILEIRO DE ENGENHARIA AGRÍCOLA, 26, 1997, Campo Grande, Anais... Jaboticabal : SBEA, 1997. 1 CD. 
REIS, A. V. Máquinas e mecanismos dosadores para a semeadura de precisão. Santa Maria, 2000. 78p. Monografia (Estudo dirigido) - CTC/EMC, Universidade Federal de Santa Catarina, Florianópolis, 2000 .
REIS, A. V., ALONÇO, A. S. Comparativo sobre a precisão funcional de vários mecanismos dosadores estudados no Brasil entre os anos de 1989 e 2000. In: CONGRESSO BRASILEIRO DE ENGENHARIA AGRÍCOLA, 39, 2001, Foz do Iguaçu. Anais... Jaboticabal : SBEA, 2001. 4 p. 1 CD. 